\title{
PROJECT SELECTION FOR GROUP DECISION MAKING: A MULTIPLE PROJECT PERSPECTIVE FROM PAKISTAN ${ }^{1}$
}

\author{
Muhammad Farhan BASHEER ${ }^{2}$ \\ Muhammad IMRAN ${ }^{3}$ \\ Siti Norasyikin Abdul HAMID ${ }^{4}$ \\ Azelin AZIZ
}

\author{
Received Date (Başvuru Tarihi): 01/11/2018 \\ Accepted Date (Kabul Tarihi): 15/11/2018 \\ Published Date (Yayın Tarihi): 30/11/2018
}

\begin{abstract}
Decision making is one of the primary functions of management. Making strategic decisions are important to achieve organisational efficiency and effectiveness. In the selection of projects, it is necessary for organisations to prioritise their projects due to limited resources. Therefore, the selection of projects that bring value and substantial impact on the organisation is very important to ensure that they can compete in the dynamic external environment and meet the goals and objectives. From the case study, the result suggests that the Analytical Hierarchy Process (AHP) method can contribute significantly to the identification of sources that need further clarification of attributes and criteria and at the same time it can provide a systematic analytical tool in making a group decision. This method allows the organisation to prioritize its projects based on certain criteria as it is a quantitative decision support tool. In conclusion, AHP is the best and efficient method for decision makers to consider all facts, weigh the pluses and minuses, reach, reevaluate and communicate their decisions.
\end{abstract}

Keywords: Decision Making, AHP Method, Project

JEL Codes: C12, C61

\section{GRUP KARAR VERME PROJESİ SEÇIMII: PAKISSTAN'DAN ÇOKLU BİR PROJE PERSPEKTIFI}

ÖZ

Karar verme, yönetimin temel işlevlerinden biridir. Stratejik kararlar vermek, organizasyonel etkinlik ve verimlilik elde etmek için önemlidir. Projelerin seçiminde, kuruluşların sınırlı kaynaklardan dolayı projelerini önceliklendirmesi gerekmektedir. Bu nedenle, organizasyona değer ve önemli etki yaratan projelerin seçimi, dinamik dış ortamlarda rekabet edebilmelerini ve amaç ve hedefleri karşılayabilmelerini sağlamak için çok önemlidir. Vaka çalışmasından elde edilen sonuç, Analitik Hiyerarşi Süreci (AHP) yönteminin, niteliklerin ve kriterlerin daha fazla açıklığa kavuşturulması gereken kaynakların tanımlanmasına önemli ölçüde katkıda bulunabileceğini ve aynı zamanda bir grup kararında sistematik bir analitik araç sağlayabileceğini göstermektedir. Bu yöntem, kurumun projelerini nicel bir karar destek aracı olduğu için belirli kriterlere göre önceliklendirmesine izin verir. Sonuç olarak, AHP'nin, karar vericilerin tüm gerçekleri dikkate almalarnı, artıları ve eksileri değerlendirmelerini, ulaşmalarını, yeniden değerlendirmelerini ve kararlarını iletmelerini sağlayan en iyi ve etkili yöntem olduğu söylenebilmektedir.

Anahtar Kelimeler: Karar Verme, AHP Yöntemi, Proje

JEL Kodları: C12, C61

\footnotetext{
${ }^{1} \mathrm{Bu}$ çalışma "Business and Organization Research Conference-BOR 2018" adlı kongrede yayınlanmıştır.

${ }^{2}$ School of Economics, Finance and Banking, Universiti Utara Malaysia, Sintok, Kedah, Malaysia, khwaja.farhan7@gmail.com https://orcid.org/0000_ $0001-8622-9866$

${ }^{3}$ School of Business Management, Universiti Utara Malaysia, Sintok, Kedah, Malaysia, Imran.imranb2001@gmail.com https://orcid.org/0000-00017126-2831

${ }^{4}$ School of Business Management, Universiti Utara Malaysia, Sintok, Kedah, Malaysia, norasyikin@ uum.edu.my https://orcid.org/0000-0002-9130$\underline{3650}$

$\frac{36}{5}$ School of Business Management, Universiti Utara Malaysia, Sintok, Kedah, Malaysia, azelin@uum.edu.my
} $\underline{121 X}$

Business \& Management Studies: An International Journal Vol.:6 Issue:3 Year:2018, pp. 190-203 


\section{INTRODUCTION}

Decision making is important for any organisation (Saaty, 2008). Many organisations are now expanding their operations involving project management (ibid). Making a decision is the result of a mental process of choosing some actions from several alternatives. A wrong decision can cost organisations in various ways. While making decision, the factor of human capital is equally important because people, as humanbeings, are involved in decision-making process. "Human capital is a factor that should be considered as being a form of competitive advantage for organisations because it is the collection of all of the intelligence, experience, and insights of organisational members" (Aydin and Rahman, 2017). Hence, human capital enables organizations in gaining competitive edge and their experiences help organizations in making right decisions. Every decision-making process produces a final choice of action or opinion. If a person neither acts nor gives an opinion, a decision is also made (Saaty, 2008). Most decisions involve analyzing the existing selection set or using a part of the criteria set. These criteria may cause benefit or cost to the organization. Decision making is a part of the managerial task and for a good decision to be made, all information, regarding planning and the environment, must be known. Decision making currently is a mathematical science. It formulizes thinking process so better decisions can be made. To make a good decision, some fundamental understanding of the valuable processes are need to be known (Saaty, 2008).

Decision making always involves a choice among alternatives. A decision maker needs information on which base to found his/her judgement; without information, decisions are no more than an inspired guesswork. According to Simon (2011), knowledge management is a part of the whole process of managerial decision making. According to Saaty (2008), a good decision means making the right choice that satisfies many needs, for the greatest advantage. Generally, there are three levels of decision making. They are strategic, tactical and operational. The strategic level is the highest level of decision, the least structured, most imaginative, risky, and produces the most uncertain outcome. Such decisions are taken mostly at the Board of Director's level. The tactical level supports the strategic level. Tactical decisions are medium range and have medium significance with moderate consequences. The operational level is the lowest level, used in operational, short range and usually involves low cost (Ang, 2005). In making decision, a manager is responsible in identifying problems, determining the types of problem, finding the right solutions, assessing potential solutions and formulating strategies for solving the problems. According to Ricardo (2010), due to ever changing in dynamic current environment, selecting and making the right choices based on aligned objectives is a critical factor for the organizational survival. 
Decision making is not necessarily made by an individual person; currently, many organisations involve group decision making. Making decisions as a group is known as collaborative decision making, which occurs when individuals join in selecting from a range of choices. In group decision making, a member's contribution directly affects the decision made (Sa, 2011).

According to Ang (2005), group decisions have a greater risk or opportunity than individual decisions and it typically requires numerous meetings. Therefore, what the decision makers need is a better approach to decision making that allows the necessary requirements on the alternatives. This is due to the environment being complex with having higher multiplicity, flux, interdependence and ambiguity (Haque, Aydin and Uysal, 2017). "In the situation of multiplicity where frequency of likely interacting attributes increases. As the organisation grows, the managerial roles are not confined to small number of stakeholders but the numbers of stakeholders multiply at constantly changing rate so decision-making, negotiation, action roles, communication, and even emotional stability are to be ensured by leaders (Haque et al., 2017). One structured approach to decision making that may work well, is Analytical Hierarchy Process (AHP), which uses simple judgment known as pair-wise comparison. An example of decision making is human resource decision (Rubin, 1991), decision making on supplier selection (Athawale, Mukherjee and Chakraborty, 2009) and project selection (Palcic and Lalic, 2009).

According to Powers, Ruwanpura, Dolhan, and Chu (2002), project selection is the process of assessing individual projects, that is, selecting projects based on a specific analysis on how best to achieve the organizational objectives. It involves an analysis of the importance of the financial aspects of the project to determine the most optimum of the available alternatives. Srivannaboon and Milosevic (2006) showed that most organisations try to implement their corporate strategies through projects. Archer and Ghasemzadeh (1999) said that successful selection of a project is the result of the right set of projects for implementation of corporate strategies.

With limited resources and capabilities, selecting the right project and right mix of projects in the portfolio is an important task for the organization to achieve its corporate goal (Englund and Graham, 1999). According to Parcic and Lalic (2009), to save cost and enjoy maximum benefits, selection of a project must be made. A project can be very complex or very routine; regardless of the nature of the project, it involves constraints in terms of time, budget and resources. According to Clifford (2003), one of the aims of a project is to meet the stakeholder's needs. According to Mwosa (1987), projects are like planning to build blocks, which success depends on translating the plans into reality. Managers can plan effectively on how the available resources can be used to meet the organizational objectives. 
The three projects planned have their own set of challenges and problems, as follows: (a) lack of information on financial matters; (b) lack of strategic alliances with the project objectives; (c) procedural requirements from regulatory bodies; and (d) lack of resources. Due to these factors and limited resources, prioritization of the project is the first strategy that the college needs to decide. Selecting the best project that optimizes the college's resources is very important. To achieve this, determining the project criteria and important factor is crucial. However, many project managers today use their judgement to select the best project. Selection of projects is a very important decision because if the projects are not able to be completed on time and incur more costs, it can affect the image and effectiveness of the company (Iman and Siew, 2008). Therefore, the present research recommends that decision makers use Analytical Hierarchy Process (AHP) method to select the criteria and prioritize the projects.

The purpose of this research is to recommend managers about the selection criteria that need to be considered in prioritizing the project and assisting them in evaluating and selecting the project that can maximize the resources the company has. Hence, the objectives of this research are:

1. To identify the criteria for selecting the most appropriate and relevant projects; and

2. To determine the projects those best meet the criteria of the organization

\section{LITERATURE REVIEW}

\section{Project Selection Criteria}

The term 'selection' may be defined as a process of choosing from a group of people or things (Oxford, 2005). The term 'criterion', on the other hand, is defined in the Oxford dictionary (2005), as a standard or principle determinant in decision making or judgement. Therefore, 'selection criteria' used in this research is defined as a list of criteria used to evaluate projects for a good selection. Ricardo (2010) identified six criteria of selection of projects. In his case study on ACME organization, the criteria and sub-criteria for selecting projects were stakeholder's commitment (team commitment, organizational commitment and project manager commitment), financial indicators (return on investment, profit and net present value), strategies of the companies (improve ability to compete in international markets, improve internal processes and improve reputation) and other criteria (lower threat for the organization, urgency, and internal technical knowledge). Melone and Wharton (1984) discussed three criteria of project selection. They are financial benefits, contribution to organizational strategy, and contribution to IT structure. Pinto (2007) suggested the following criteria of project selection: technical risk, financial criteria, safety criteria, quality and legal exposure, expected return on investment, payback period of the investment, potential market share and ability to generate new projects. 


\section{Financial Aspect}

Palcic and Lalic (2009) used financial benefit as a criterion in selecting and evaluating projects. Financial benefit focuses on the physical benefits of the project, which are subdivided into short term and long-term benefits. Commonly, many organisations or business today develop standard ROI calculator using Net Present Value (NPV) and Internal Rate of Return (IRR) to measure the performance of the projects. Motta and Quintella (2012), used financial and non-financial criteria to select an investment project. An example of a financial criterion was need for capital (Basheer, 2014: Basheer et al, 2019), while nonfinancial criteria were assessment of team and technology. Other financial criteria include assessment of market and divestment, which were combined with market size, volume of transactions, and availability of investment resources. Other non-financial aspects like qualitative market evolution and strategic interests of players in the area were also considered.

In general, many organisations select projects based on financial criteria. If a project can resolve issues relating to the user and allows the aid in the growth of the organization, the projects are selected, otherwise they are rejected. Larson and Gray (2011) argued that when there is high confidence in the estimates of future benefits in terms of profit, financial measures are used. To them, profit return is important for a project, but this return should not be the only criterion in a project selection process. A firm's core competencies and long-term performance should also be considered.

\section{Strategy}

This criterion is very important to achieve corporate strategy because the projects are the manifestation of the company's strategy. Cooper et al. (2000) argued that corporate strategy must be aligned in the project selection and resource allocation to those projects. However, to assess the effectiveness of a project that contributes to the objectives of the company or its corporate strategy is not a simple matter since strategy is dynamic and constantly changing. Furthermore, strategy is different from one organization to the other (Imran, Hamid and Aziz, 2018). According to Le and Nguyen (2007), to select the right projects which contribute to the successful implementation of the corporate strategy is very challenging. Seeber (2011) stated that one of the criteria to be considered in selecting a project is strategic fit with the mission of the projects. To him, if the organization lacks strategic fit with the mission, the organization has failed in project selection (Imran et al., 2018). Palcic and Lalic (2009) used contribution to organizational strategy as one of the criteria, which was subdivided into three: increasing market share, retaining existing customers and improve cost management.

According to Ricardo (2010), one of the criteria that can be used in prioritizing projects is strategy. The common method to measure corporate strategy is Balanced Scorecard. This method is different from financial criteria because strategic criteria are specific to an organization (Imran, Aziz 
and Hamid, 2017; Javed and Basheer, 2017). Not all organisations have the same strategy and these strategies have different prioritization criteria (Imran, Aziz and Hamid, 2016, 2017a, 2017b). Examples of different strategies and goals are to increase the production, to compete in international markets, to optimize internal processes, to lessen costs and to compare and to benchmark to competitors and to improve the reputation of products and services.

\section{Risk}

According to Zou (2007), the selection process is unique because it always has to deal with risk and risk management. These selection criteria should be considered when making selection decision. According to Pinto (2010), risks in project selection criteria are technical risk, financial risk, safety risk, quality risk, and legal exposure. The AHP, as shown by Mustafa and Al-Bahar (1991), provides both a subjective and objective approach to risk analysis using expert judgement. However, this approach cannot integrate these risk analyses with the project management processes. Recently, Zayed et al. (2008) have applied the AHP to assess risk in Chinese highway projects. The framework prioritizes risk factors and ranks alternative projects. However, their approach does not discuss on how to manage risk during the planning and implementation phases of the projects as indicated in the project risk management standards. Dey (2008) used the AHP method to identify five risks in oil redefining industry. They were technical risk, financial and economic risk, organizational risk, natural hazards and statutory clearance risk.

\section{Contractor Availability}

In case study conducted by Al Subhi, (2001), contractor availability was used as a selection criterion in project management. To determine a set of criteria that are necessary to determine the contractor's competence and ability in project bid, the screening by construction contractors was used. The contractor availability criteria such as experience, financial stability, quality performance, manpower resources, equipment resources, and current workload were determined for these project selection criteria. Bertolini et al. (2006), and Mahdi and Alreshaid (2005) proposed the application of the AHP method in their work. In their case studies, they used this method to select the service providers in the public sector and highlighted 31 decision criteria, of which the most important were cost, public work contract type involving penalties, price and changes during work, risk, type of work, availability of material and taskforce and conflict of interests between owner and contractor.

\section{Technical Knowledge}

Technical knowledge is necessary to execute a project. The more the technical knowledge available for the projects and environment, the easier it will be to execute any given project and, consequently, it will cause the project to use fewer resources (Ricardo, 2010: Basheer et al., 2018). Ricardo used technical knowledge criterion to prioritize the projects. Wheeler (2013) identified several 
criteria in project selection. They were culture of the organization, process incurred in the projects, knowledge of the business and works, experience gained on projects, corporate governance, risk awareness on the projects, and time pressures. All these factors had significant effect especially on public sector organisations, private sector organisations and government-owned corporations. As a result, these corporations must have a strong linkage to research on strategic decision making.

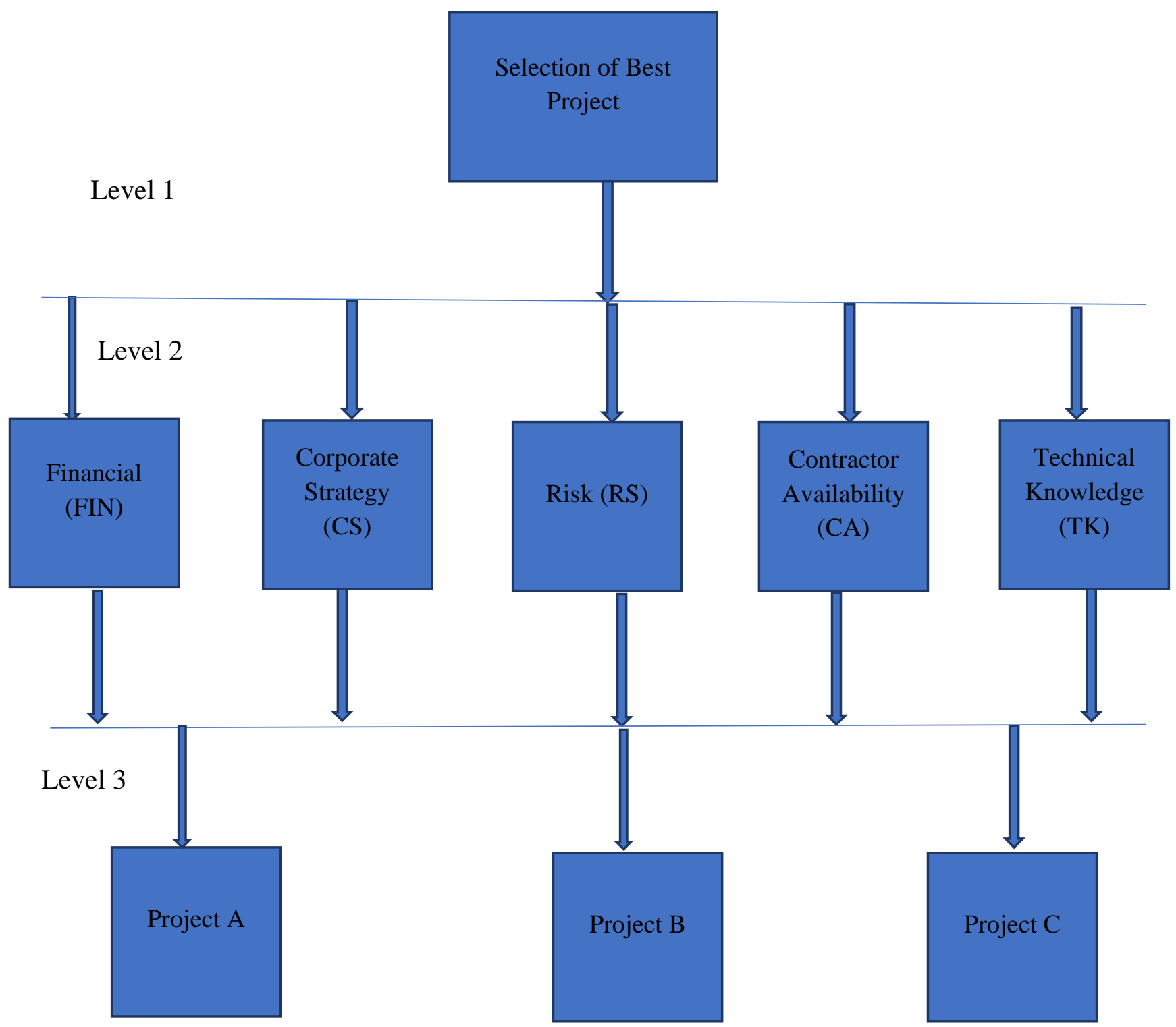

Figure 1. Decision Hierarchy Structure

\section{The Analytical Hierarchy Process}

Dr. Thomas Saaty developed the Analytical Hierarchy Process (AHP) in the late 1960's. His goal was to develop a simple, consistent way to make complex decisions. The AHP is an effective method developed to overcome decision difficulties by using weighted criteria. Analytic Hierarchy 
Process relies on three fundamental assumptions deduced from the words of the technique (Mahdi, 2005). The AHP benefits group decision making because group members can use their experience, values and knowledge to break down a problem into a hierarchy and solve it by the AHP steps.

In 2005, Mahdi, an Associate Professor from Chemical Engineering Department, College of Engineering and Petroleum, Kuwait University, presented a case study on the use of AHP method in Kuwait's Power Station Air Pollution Control. He found that AHP allows the use of non-quantifiable parameters such as environmental, social and political criteria besides quantifiable cost-effective technical and economic factors. Palcic and Lalic (2009) used AHP in project selection in assigning priority and for making appropriate decisions. In his case research on information technology-oriented company, Henny (2006) applied the AHP approach to design a structural model of the decision-making process in which AHP plays a role.

\section{Methodology}

Cross sectional research design was used because the data collection was completed within three months. To gather the data, snowball sampling technique was used because the main target audiences were top management and executives primarily involved in the decision-making process. Thus, the referral technique suited most to the research objectives. We targeted the one of the most advanced and largest enterprise of Pakistan, Bahria Town Real Estate and construction firm involved in over 1,000 construction projects. The reason for selecting Bahria Group is, the fact that it is the only group to have a construction project in every major city of Pakistan. Open-ended survey was used as research instrument. According to the official list 87 total employees working at executive level in the top management was attained from the firm's official website. Thus, we ensured that majority of the respondents could be included, hence, we set the criteria of majority being over $50 \%$. By reaching 48 respondents, attained $55.1 \%$ was attained, reflecting that we had clear over $50 \%$ target population to draw conclusion. The tri-angulation approach was used to ensure the reliability and validity aspects. We also considered appropriate steps to ensure ethical considerations are kept intact. Furthermore, Analytical Hierarchy Process (AHP) was used to investigate the decision-making process at Bahria Group.

\section{Results and Discussion}

The respondents had an average of 15 years of service with the company. Of 48 respondents, $29(60.41 \%)$ were frequently involved in decision-making while remaining 19 (39.59\%) were involved on immediate basis. With regards to educational qualification, majority of the respondents had Master's degree (52\%) in relevant field with over 15 years of experience suggesting that they 
qualified in evaluating and selecting the most appropriate projects to be prioritized in the company. In addition, all the respondents considered the criteria when selecting of the projects.

\section{AHP Analysis}

AHP methods was used to analyse the five selection criteria. These include pair-wise comparison, calculating the relative weights and eigenvector and the consistency ratio. The establishment of priority among criteria was based on pair-wise comparisons. They tabulated into the pairwise comparison matrix to assess the criteria. In the pair-wise comparison matrix, the diagonal elements are always equal to one, and the lower triangle elements of the matrix are the reciprocal of the upper triangle elements (Zahedi, 1986).

Table 1 shows the data collected from the General Managers. The first row ranked scale of five, means Financial is strongly more important to Strategic criteria. Ranked scale of three, means Financial is moderately more important to Risk criteria and ranked scale of four, means Financial is moderately strongly more important to Urgency.

Table 1. Pair-wise Comparison for Criteria - General Manager

\begin{tabular}{cccccc}
\hline Criteria & FN & ST & RK & CA & TK \\
\hline FN & 1.0000 & 2.0000 & 4.0000 & 3.0000 & 4.0000 \\
ST & 3.0000 & 1.0000 & 5.0000 & 2.0000 & 3.0000 \\
RK & 2.0000 & 4.0000 & 1.0000 & 5.0000 & 2.0000 \\
CA & 5.0000 & 3.0000 & 4.0000 & 1.0000 & 5.0000 \\
TK & 4.0000 & 2.0000 & 5.0000 & 3.0000 & 1.0000 \\
\hline
\end{tabular}

When comparing between the financial and strategic criteria position, it means that the Financial criterion was five times more important that the Strategic criterion. One always enters the whole number in its appropriate position and automatically enters its reciprocal in the transpose position.

Table 2. Normalized Matrix

\begin{tabular}{llllll}
\hline Criteria & FN & ST & RK & CA & TK \\
\hline FN & 0.447 & 0.526 & 0.419 & 0.286 & 0.470 \\
ST & 0.190 & 0.105 & 0.270 & 0.143 & 0.059 \\
RK & 0.149 & 0.053 & 0.139 & 0.214 & 0.235 \\
CA & 0.134 & 0.190 & 0.046 & 0.123 & 0.133 \\
TK & 0.080 & 0.126 & 0.126 & 0.234 & 0.103 \\
Total & 1.000 & 1.000 & 1.000 & 1.000 & 1.000 \\
\hline
\end{tabular}


Table 3. Ranking

\begin{tabular}{ccc}
\hline Criteria & Priority & Ranking \\
\hline FN & 0.347 & 0.526 \\
ST & 0.290 & 0.105 \\
RK & 0.159 & 0.053 \\
CA & 0.124 & 0.190 \\
TK & 0.080 & 0.126 \\
\end{tabular}

The consistency ratio considering that humans are error-prone and often inconsistent, the AHP allows some degree of errors and inconsistencies in the decision maker's judgments (Min, 1992). The consistency ratio tells us how consistent we are with our ranking. A higher number means we are less consistent, whereas a lower number means that we are more consistent. According to the rule of thumb suggested by Saaty (1980), a consistency ratio (CR) of 0.10 (10\%) or less is considered an acceptable margin; otherwise, the decision maker should then reevaluate his/her ranking scores. Figure 4.1 is the formula and calculation of the consistency ratio.

$\mathrm{CR}=$ Consistency index $(\mathrm{CI}) /$ Random index $(\mathrm{RI})$

Where $\mathrm{CI}=\lambda-\mathrm{n} / \mathrm{n}-1$

$\mathrm{n}=$ number of decision elements in the consideration

$\lambda=$ the average value of consistency vector

$\mathrm{RI}=$ mean CI of a randomly generated reciprocal matrix from a ratio scale of 1 to 9, as in Table 4 (Render \& Stair, 2000).

Table 4. Random Index

\begin{tabular}{cc}
\hline Criteria & Priority \\
\hline 2 & 0 \\
3 & 0.58 \\
4 & 0.9 \\
5 & 1.12 \\
6 & 1.24 \\
7 & 1.32 \\
8 & 1.41
\end{tabular}


Table 5. Weighted Sum Vector and Consistency Vector

\begin{tabular}{lllllllll}
\hline Criteria & FN & ST & RK & CA & TK & Priority & $\begin{array}{l}\text { Wt. Sum } \\
\text { Vector }\end{array}$ & $\begin{array}{l}\text { Consistency } \\
\text { vector }\end{array}$ \\
\hline FN & 1.0000 & 2.0000 & 4.0000 & 3.0000 & 4.0000 & 0.347 & 1.567 & 5.476 \\
ST & 3.0000 & 1.0000 & 5.0000 & 2.0000 & 3.0000 & 0.290 & 1.453 & 5.565 \\
RK & 2.0000 & 4.0000 & 1.0000 & 5.0000 & 2.0000 & 0.159 & 0.826 & 5.295 \\
CA & 5.0000 & 3.0000 & 4.0000 & 1.0000 & 5.0000 & 0.124 & 0.878 & 5.317 \\
TK & 4.0000 & 2.0000 & 5.0000 & 3.0000 & 1.0000 & 0.080 & 0.479 & 5.601 \\
\hline
\end{tabular}

Subsequently, the value of lambda $(\lambda)$ was computed by taking the average value of the consistency vector, i.e. $(5.476+5.565+5.295+5.317+5.601) / 5=5.449$. Therefore, $C I=(\lambda-n) /(n-1)=(5.449$ $-5) / 5-1=0.112 \mathrm{CR}=$ consistency index $(\mathrm{CI}) /$ random index $(\mathrm{RI})=0.011 / 1.13=0.0091$. In this case, the CR 0.009 shows that pair-wise comparison was deemed consistent within the acceptable random variations for this decision maker.

Table 6. Summary of Results for AHP Analysis

\begin{tabular}{ccc}
\hline Selection Criteria & Wt & Rank \\
\hline Project C & 0.435 & 1 \\
Project B & 0.355 & 2 \\
Project A & 0.210 & 3 \\
\hline
\end{tabular}

Based on the results from the AHP method and the objectives of the research to identify selection criteria that are the most appropriate and relevant in project selection, financial $(\mathrm{FN})$ criterion showed the highest mean ranking of 0.389. This means that the financial aspect was the most appropriate and relevant in project selection. The group decision makers considered financial aspect as the most important criterion that impacts the organization. On the other hand, technical knowledge (TK) was the least preferred selection criterion. In determining which projects that best meet the requirements of the organization, Project $\mathrm{C}$, which had the highest mean ranking of 0.435 , should be selected. It means that the management must focus on this project in their prioritization of their projects. However, Project B had a mean ranking of 0.355 , which was not significantly different from Project A. But in terms of contractor availability (CA) and technical knowledge (TK) criteria, Project B had shown a high ranking.

\section{Conclusion}

In selection of projects, it necessary for organisations to prioritize their projects due to limited resources. Therefore, the selection of projects that bring value and substantial impact on the organisation is very important to ensure that they can compete in the dynamic external environment and meet the goals and objectives. From the case study, the result suggests that the AHP method can 
contribute significantly to the identification of sources that need further clarification of attributes and criteria and at the same time providing a systematic analytical tool in making group decision. In conclusion, AHP is the best and efficient method for decision makers to consider all facts, weigh the pluses and minuses, reach, reevaluate and communicate their decision.

In respect of implication, this research helps to owners / managers for effective decision making for the selection of new project. Furthermore, the right decision making, and right selection of project leads to higher firm performance. However, this research findings are not only beneficial for student's project selection, this is beneficial for business firms as well. 


\section{REFERENCES}

Ang. (2005). Using AHP in ERP software for group decision making. Unpublished technical report, Universiti Utara Malaysia, Sintok.

Alexander, L. G., \& McKeown, T. J. (1985). Case studies and theories of organizational decision making. Advances in Information processing in Organizations, 2, 2-58.

Al-Subhi, K. M. (2001). Application of the AHP in project management. International Journal of Project Management, 19, 19-27.

Andrew, J. C., \& Mahmoud, M. Y. (2003). Managing the project management process. Industrial Management \& Data Systems, 103(1), 39-46.

Asaka, F. O. (2008). Projects selection and management implications in Kenyan local authorities. Asian Journal of Business and Management Sciences, 1(10), 65-75.

Athawale, M. C. (2009). Supplier selection using multi criteria decision making methods. Journal of Operations Management, 8, 41-60.

Aydin, E., \& Rahman, M. (2017). Theoretical Perspectives to Diversity in Management Research. Journal of Management Research, 9(2), 160-170.

Bhushan, N., \& Rai, K. (2004). Strategic decision making: Applying the analytic hierarchy process. New York: Springer.

Basheer, M. F., KhorramI, A. A. A., \& Hassan, S. G. (2018). PATRONAGE FACTORS OF ISLAMIC BANKING SYSTEM IN PAKISTAN. Academy of Accounting and Financial Studies Journal, 22, 1-9.

Basheer, M., Ahmad, A., \& Hassan, S. (2019). Impact of economic and financial factors on tax revenue: Evidence from the Middle East countries. Accounting, 5(2), 53-60.

Basheer, M. F. (2014). Impact of Corporate Governance on Corporate Cash Holdings: An empirical study of firms in manufacturing industry of Pakistan. International Journal of Innovation and Applied Studies, 7(4), 1371.

Burton, C., \&Suedel, J. K. (2009). Comparison of the direct scoring method and multi criteria decision analysis for dredged material management decision making.

Charvat, J. (2003). Project management methodologies: Selecting, implementing, and supporting methodologies and processes for project. Hoboken, New Jersey: John Wiley \& Sons, Inc.

Clifford, F. C., \& Larson, W. E. (2003). Management process (2nd ed.) New York: McGraw-Hill Ltd.

Colin, O. B. (1985). A linear goal-programming model for public-sector project selection. The Journal of the Operational Research Society, 36(1). 13-23.

Costa, H. R., Barros, M. O., \& Rocha, A. R. C. (2010). Software project portfolio selection: A modern portfolio theory based technique. Proceedings of the 22nd Software Engineering and Knowledge Engineering Conference. San Francisco, EUA.

Eddie W. L. (2002). Analytical hierarchy process: A defective tool when used improperly. Measuring Business Excellence, 6, 33-37.

Haque, A. U., Aydin, E., and Uysal, E. (2017). A Comparison of Effectiveness of Global Leaders and Domestic Leaders in Electronic Retail Industry, The Global Journal of Management Research, 17(2), 11-20.

Imran, M., Aziz, A., \& Hamid, S. (2016). Moderating role of environmental turbulence on the relationship between entrepreneurial orientation, business networks orientation, export market orientation and SMEs export performance: a research framework. Journal of Business Management, Commerce \& Research, IV(XV).

Imran, M., Aziz, A., \& Hamid, S. (2017a). The Relationship between Entrepreneurial Orientation, Business Networks Orientation, Export Market Orientation and SME Export Performance: A Proposed Research Framework. International Journal of Academic Research in Business and Social Sciences, 7(10), 230-248. doi:10.6007/IJARBSS/v7-i10/3372 
Imran, M., Aziz, A., \& Hamid, S. (2017b). Total Quality Management, Export Market Orientation and Firm Export Performance: A Conceptual Framework. International Journal of Academic Research in Business and Social Sciences, 7(9), 591-601. doi:10.6007/IJARBSS/v7-i9/3382

Imran, M., Aziz, A., \& Hamid, S. (2017). Determinants of SME export performance. International Journal of Data and Network Science, 1(2), 39-58.

Imran, M., Aziz, A., Hamid, S., Shabbir, M., Salman, R., \& Jian, Z. (2018). The mediating role of total quality management between entrepreneurial orientation and SMEsexport performance. Management Science Letters, 8(6), 519-532.

Imran, M., Hamid, S., \& Aziz, A. (2018). The influence of TQM on export performance of SMEs: Empirical evidence from manufacturing sector in Pakistan using PLS-SEM. Management Science Letters, 8(5), 483-496.

Javed, M. A., \& Basheer, M. F. (2017). Impact of external factors on bank profitability. EPRA International Journal of Research and Development, 2(5), 1-11.

Kendrick, J. D. (2007). Use of analytic hierarchy process for project selection. Six Sigma Forum Magazine, 5, 23-25.

Mahdi, K. A. (2002). Project selection by analytical hierarchy process: Case research-- Kuwait's power station air pollution control. Management Institute, 3, 67-72.

Mazur, J. L. (2005). Quality infrastructure improvement using QFD to manage project priorities and project management resources. International Journal of Quality \& Reliability Management, 22, 10-16.

Melone, N. P., \& Wharton, T. J. (1984). Strategies for MIS project selection. Journal of Systems Management, 4, $26-33$.

Morris, W. G., \& Pinto, K. J. (2007). The Wiley guide to project organization and project management competencies. New Jersey: John Wiley and Sons.

Motta, G. S., \&Quintella R. H. (2012). Assessment of non-financial criteria in the selection of investment projects for seed capital funding: The contribution of scientometrics and patentometrics. Journal of Technology Management \& Innovation, 7(3), 5-7.

Mullins, J. L. (2005). Management and organizational behavior. Essex: Pearson Educ. Ltd.

Palcic and Lalic. (2009). Analytical hierarchy process as a tool for selecting and evaluating projects. Journal of Management, 3, 45-53.

Pinto, J. (2007). Project management: Achieving competitive advantage. UK: Pearson Education.

Pinto, J. K., \&Slevin, D.P. (1987). Critical factors in successful project implementation. IEEE Transactions on Engineering Management, 34(1), 22-7.

Powers, Ruwanpura, Dolhan, and Chu. (2002). Simulation based project decision analysis tool. Journal of management project, 5, 32-40.

Ricardo, V. V. (2010). Using the analytic hierarchy process (AHP) to select and prioritize projects in a portfolio. International Journal of Management, 12(2), 321-333.

Ricardo, V. V. (2011). Urgency: A critical factor in project planning. International Journal of Management, 14(3), 231234.

Rubin, R. E. (1991). Human resource management in libraries: Theory and practice. New York: Neal-Schuman.

Saaty, T. L. (1980). The analytic hierarchy process. New York: McGraw-Hill.

Saaty, T. L. (2008). Decision making with the analytic hierarchy process. International Journal of Services Sciences, 1(1), 83-98.

Swinscow TD, Campbell MJ. (2003). Statistics at square one. 10th ed. New Delhi, India: Viva Books Private Limited.

Triantaphyllou, E. (2002). Multi-criteria decision making methods: A comparative research. New York: Springer 